\title{
Development Rights : An Application Model Of Education For Juvenile In Juvenile Prison
}

\author{
Irma Cahyaningtyas \\ \{irmafjr83@gmail.com\} \\ Faculty of Law Diponegoro University, Prof Sudarto Tembalang Semarang- Central Java ${ }^{1}$
}

\begin{abstract}
Child protection is a part of national development. One of the components to provide child protection is implemented by involving Juvenile Criminal Justice System. One of such subsystems is a Prison for juvenile as a facility to guide juvenile who are sentenced by the court. Speaking of how the juvenile is guided within the prison, there is a right for a child namely development rights. Research problem in this article are first, how to implement development rights for juvenile within the Juvenile Prison; second is how to construct model of education for juvenile within the Juvenile Prison at the future. This article uses juridical empirical research methodology. The used approach was sociolegal approach. The research was conducted in juvenile prison in Kutoarjo, Central Java. The implementation of development rights for juvenile in juvenile prison is applied based on the regulation either international or national law. The form of development rights application in prison would be that the juvenile have the right to have physical and spiritual treatment; education and teaching;; reading materials or information from mass media outside the juvenile prison. In the future, the application of development rights must be supported by the help from the guide, family and from the people so that once they are graduated, the juvenile would have been educated, skilled and have the expertise for their provisions to carry on the life once they go out of the prison.
\end{abstract}

Keywords: Juvenile; education model; development rights; juvenile prison.

\section{Introduction}

Implementation of national goal in order to realize Indonesian national aspiration towards justice and welfare society based on the Pancasila and The 1945 Constitution, is realized by the presence of national development program. Child protection in terms of guidance is the thing that must be given to children. Law protection is a right of a child that can be seen from the presence of international document related to the child's issue.

The various international document could also be seen as an effort of law protection for children [1], even though it is still in the form of a statement (declaration), agreement/treaty (convention) and resolution or even it is still a guideline. Speaking of the right of a child, the right to develop or it could also be said as development rights, which are the rights of a child in Convention on the Rights of the Child including any form of education (formal and informal) and the right to reach appropriate standard living for children's physical, mental, spiritual, moral and social development.

In its implementation, especially in the maintenance of the presence of development rights, it still has many weaknesses, among them, are the implementation of the right to receive education for children who is having guidance in prison as well as the right to receive 
health care which is still far from the adequate health standard, in addition to the development right in terms of nutrition fulfilment for children who are having the guidance.

Another article examining those right of children is discuss about young children have the right to development and cultural understanding [2]; other article discuss about the embeddedness of children within key relationships and the transformative nature of age-based difference [3]; in other article discuss about children of depressed mothers are at risk for health, developmental, and behavioral problems [4]; in other article discuss about there is an overpresentation of student identified as having disabilities, especially emotional disturbance in those system [5]. In this article has more focused in application of development rights in juvenile prison to emphasis on educational program.

\section{Method}

Research also needs a certain method. The role and function of methodology in research explain that methodology substantially provides guidance about how a scientist learns, analyses, and understands the environment is facing [6].

Method of approach towards such an issue is empirical jurisdiction approach. Jurisdictionally, since the issues which is about to examine are the norms of law applied and its implementation. While empirically, since the law is seen as identical to patterning behavior and the understanding of social meaning. Such empirical approach could be used to identify the implementation of development rights for the juvenile in juvenile prison.

Related to the data used in this research obtained from the primary data with the Supervisor of the Prisoner as the respondent. This research was carried out in juvenile prison in Kutoarjo, Central Java. The secondary data is the data obtained from the literature of the research in order to collect theoretical foundation in the form of opinion, writing from the experts or other authorized parties as well as to obtain information both in the form of formal provision or data through the existing official article. Besides, it also analyses through the implementation of the rule of law.

\section{Results and Discussion}

Definition of a child in United Nations Standard Minimum Rules for The Administration of Juvenile Justice [7] in Rule 2.2 (a) states that a juvenile is a child or young person who, under the respective legal systems and concepts.

Convention on the Rights of the Child [8] categorizes 4 groups of children's rights, namely:

a. Survival Rights; it is the children's rights to the rights of life and the rights to the highest standard of health and medical care attainable;

b. Protection Rights; it is children's rights in convention including the right of protection from discrimination, bullying, and displacement for the children who do not have family and the children of refugee;

c. Development Rights; it is children's rights including any kind of education (formal and informal) and appropriate standard of living for children's physical, mental, spiritual, moral and social; 
d. Participation Rights; it is children's rights to express their views in all matters affecting that child.

The four principles of children's right as the basic rights of the children could highly be respected to be applied for each child disregarding their background, ethnicity, tribe, religion, social group, as well as the things faced by the children including those who are involved in the court of law.

In the practice in Kutoarjo Juvenile Prison, there are many children as juvenile in the juvenile prison. It is in accordance with the following data descripsion :

Table 1. The Number of Juvenile in Kutoarjo Juvenile Prison in 2014-2018

\begin{tabular}{lll}
\hline Year & Capacity & Number of Juvenile \\
\hline 2014 & 65 & 49 \\
2015 & 65 & 55 \\
2016 & 65 & 76 \\
2017 & 65 & 76 \\
2018 & 65 & 46 \\
\hline
\end{tabular}

Table 1 states the capacity in Kutoarjo Juvenile Prison is 65 children as juvenile but the reality in 2016 until 2017 is filled with 76 children. This was over capacity. The different conditions exist in the year 2014, 2015 and 2018 where there are about 46-55 of children as juvenile. It implies that as many as 65 children need development rights such as education in the juvenile prison.

The implementation of development rights has become the responsibility of all parties. The form of implementation of development rights in prison among them is juvenile prison which is a place to correction.

1. Juvenile who are in juvenile prison have a right to obtain physical and spiritual treatment. It goes along with what is written in Article 14 letter (b) of Law Number 12 of 1995 about Prison that physical care is to give opportunities to exercise and recreation; to provide clothes; to provide sleeping and cleaning equipment. Such a tool provides is carried out once the Criminal Child of the prison has been registered.

Such provision goes along with the United Nations for the Protection of Juvenile Deprived of Liberty [9] the correction institution must fulfill the health requirement which could guarantee the basic needs of human being.

2. Juvenile have the right to obtain education and teaching.

Article 22 verse (1) and Article 14 verse (1) of Law Number 12 of 1995 about Prison rule out that Criminal Children have the right to have education and teaching. Education and teaching in Prison are carried out according to the applying curriculum among the equal educational institute.

Such provision goes along with the provision of the United Nations for the Protections of the Juvenile Deprived of Liberty [10] article 38 stating that juvenile has the right to education suited to his or her needs and abilities and designed to prepare him or her for return to society.

3. Juvenile who have completed the education and teaching have the right to receive A Letter of Graduation from the correspondence institution. 
Article 13 of Government Rule Number 32 of 1999 in conjunction with Government Rule Number 99 of 2014 rule that each Prisoner and juvenile who have succeeded to finish their education have the right to obtain A Letter of Graduation namely STTB from the authorized institution.

4. Juvenile have the right to have reading material or information from the mass media from outside the juvenile prison.

Article 28 of the Government Rule Number 32 of 1999 jo Government Rule Number 99 of 2014 rules out that each child who wants to carry and receive reading material or information from mass media from outside the juvenile prison must have the permission from the Chief of the Prison. Such rule goes along with United Nations for the Protection of the Juvenile Deprived of Liberty article 41 that children have the right to receive information and mass media periodically

A law and sustainable development must be able to apply to create development rights for each juvenile [11]. The form of the update according to this article is by updating or combining the form of methods applied for the juvenile.

Theoretically, there are 5 (five) methods of guidance known regarding the guidance of juvenile, as follows.

\section{a. Situational Treatment}

Human personality is influenced by individual and environmental factors. Therefore, in guiding the prisoner children, besides having to pay attention to the background, it also needs to take an environment where the guidance is carried out into account. Such a situation could be natural, social, mental, or the likes [12]. The natural situation could be in the form of the sky being cloudy, showering, earthquake, flood, heat, cold, noise, and the like. The guidance carried out in hot and noisy environment causes the students could not focus on the material being delivered. A social situation such as poor economic condition, disable, broken home family, also affect the process of guidance. Similarly, mental health. People who are carried away in a mental situation such as trauma, emotion, would relatively unable to anticipate their own future.

b. Individual Treatment

Personal guidance is given to the prisoner children individually by the officer. The prisoner children would be categorized but the guidance would still be held individually. Even though the participants are grouped but the guide must be able to identify the need, character, maturity, emotion, logic of each individual.

c. Classical Treatment

In a group, guidance could be carried out by giving some speech, question and answer, simulation, role play, or team formation [13]. Method selection depends on the material about to deliver and the purpose to achieve. It must not use one way only but it could combine various ways. Within the group guidance, the role of the group must be active, not the guide that should be more active but the prisoner children that must be more active individually not in a group. The guide is more dominant as a facilitator, motivator.

d. Experiental Learning

Learning from experience is learning about communication and learning from new experience. Either self-experience or from others. Communication is needed to avoid mistakes in communication. 


\section{e. Auto Suggestion.}

Autosuggestion is a motivation coming from within. The use of auto-suggestion means that someone tries to give a suggestion, self-influence to do an action based on the suggestion. Autosuggestion will be more effective for himself/herself, if one knows how to implement it, and has the confidence. Auto suggestion is a way to influence humans' subconscious by inserting suggestion, influence, command, to perform an action based on the suggestion given. Suggestion, influence, and command from and to her/himself, through conscious to influence the subconscious. Of course, the suggestion, influence, and the command should be the positive, and wise ones.

According to this article, the experience is the best teacher and it could happen in daily life, therefore, the experience they are having could actually be material for guidance. Guidance based on the situation, usually the officer has to be able to change the way students think, not to be influenced by the situation but to control the situation so that the guidance material could be received better.

In this article, situational guidance has more advantage than the approaching model, which is more practical since the guide does not need to collect students' aspirations. While its weakness is that the guidance material sometimes did not match with what each student needs moreover their condition is more heterogeneous. Individual Treatment guidance for example, if it is applied there would be a weakness: the guide who does not know the character of each individual and carries on the guidance in a group instead of individually. The consequence is that the material delivered would not match with the need of each individual. In the process of guidance, the guide should be more dominant in positioning themselves as facilitator, motivator, who direct so that each child prisoner could be more independent and is used to solve problems they are facing.

In the Experiental Learning field for example, if it is well communicated, the result would also be right. Within communication, there are components involved: sending, (sender); etc. In communication, all communication component must be clear that the result is also clear and understandable. The message must be clear, for if it is not, then the feedback would also not be clear. Similarly, the guide to the children prisoners. The material delivered, besides it has to be along with the background as well as their characters, it also has to be clear so that they would not have the wrong perception about the material received.

Based on the five guidance methods above, according to this article, all methods could be applied depending on the need and the objective of the guidance that is about to achieve when one would carry out guidance especially to the juvenile. The current guidance practiced in Indonesia is the guidance in the group.

The background of in-group guidance is mostly used is because the number of the guide and the prisoners to be guided is unbalanced so that the guidance in the group is more effective to be applied. The five guidance must have the support of the legal system. Lawrence M. Friedman who pointed out the components contained in the law, which are called a legal system as described as follows [14] :

1. The substance component is in the form of legal norms, be it regulations, decisions and so on all of which are used by law enforcers and those who are regulated.

2. Components called structures. It is an institution created by the legal system such as a district court, an administrative court that has the function to support the operation of the legal system itself. This structural component allows the provision of services and legal expectations regularly. The substance component is in the form of legal norms, be it regulations, decisions and so on all of which are used by law enforcers and those who are regulated. 
3. Legal components that are cultural. It consists of ideas, attitudes, hopes, and opinions about the law. This legal culture is distinguished between internal legal culture, namely lawyers and judged's legal culture, and external legal culture, which is the legal culture of a society in general.

All of legal systems which are first substance that is the rules regarding children; second structures namely juvenile justice system; and third culture consist of society. All of legal systems must operated together to achieve a goal namely child welfare.

\section{Conclusion}

Based on the explanation in this article, it can be concluded as follows development rights in juvenile prison are not yet realized. The form of development rights can be realized when got support form existing system. That are substance, structure and culture. In the future, the application of development rights could be broken down into 5 models of guidance known Situational Treatment; Individual Treatment; Classical Treatment; Experiential Learning; Autosuggestion.

In the future, the ideal aspect of application of development rights in juvenile prison is culture. The reasoning is the subject ini juvenile prison is the juvenile who is a child or young person. Other than that, the aspect is structure who is professional officer to give education for the juvenile in juvenile. It can be realized if there is development right such as educational program or recreation program in a juvenile prison facililty.

\section{Acknowledgments.}

We are grateful for the collaboration of thoughts that resulted in this paper. We thank the Faculty of Law Diponegoro University who have provided support; Kutoarjo Juvenile Prison in Central Java which has provided data; Supervisor of the Prisoner as part of juvenile justice system who have research suporting and primary data.

\section{References}

[1] D. S. Tanenhaus, Juvenile Justice in The Making, New York: Oxford University, 2004.

[2] M. Woodhead, „Early Childhood Develepment : A Questin of Rights,“ International Journal of Early Childhood, p. 79, 2005.

[3] S. C. White, „Being, Becoming and Relationship : Conceptual Challenges of A Child Rights Approach in Development,“ Journal if International Development: The Journal of Development Studies Association, pp. 1095-1104, 2002.

[4] M. M. B. P. L. E. Theodore D Wachs, „Maternal Depression : A Global Threat to Children's Health, Development, and Behavior and to Human Rights,“ Child Development Perspectives, pp. 51-59, 2009.

[5] R. B. R. P. E. L. D. M. O. J. M. P. Mary Magee Quinn, „Youth with Disabilities in Juvenile Corrections : A National Survey,“ Council for Exceptional Children, pp. 339-345, 2005.

[6] S. Soekanto, Pengantar Penelitian Hukum, Jakarta : UI Press, 1984. 
[7] U. N. S. M. R. f. T. A. o. J. J. (. B. Rules), November 1985. [Online].

[8] C. o. T. R. o. T. Child, „http://www.ohchr.org,“" November 1989. [Online].

[9] U. N. R. f. T. P. o. J. D. o. T. Liberty, „http://unodc.org,“ December 1990. [Online].

[10] U. N. R. f. T. P. o. J. D. o. T. Liberty, „http://www.unodc.org,“ December 1990. [Online].

[11] B. C. W. Larry J. Siegel, Juvenile Delinquency Theory, Practice, and Law, California: Wadsworth Publishing, 2016.

[12] F. E. Zimring, American Juvenile Justice, New York: Oxford University Press, 2018.

[13] M. O. T. Rick Ruddell, Juvenile Corrections, Great Britain: Newgate Press, 2009.

[14] L. M. Friedman, A History of American Law : Third Edition, New York: Touchstone, 2005.

[15] U. N. S. M. R. f. T. A. o. J. J. (. B. Rules), NOvember 1985. [Online].

[16] C. o. T. R. o. T. Child, „http://www.ohchr.org., “ November 1989. [Online].

[17] U. N. R. f. T. P. o. J. D. o. T. Liberty, December 1990. [Online].

[18] U. N. R. f. T. P. o. J. D. o. T. Liberty, December 1990. [Online].

[19] U. N. R. f. t. P. o. J. D. o. T. Liberty, December 1990. [Online]. 